\title{
Implementasi Pembelajaran Make A Match Untuk Meningkatkan Kemampuan Siswa Kelas X TK SMKN 2 BATU
}

\author{
Nur Azizah \\ SMK Negeri 2 Batu, Indonesia \\ nurazizahazis2017@gmal.com
}

\begin{abstract}
Understanding Quranic materials in vocational students includes understanding how to read, the meanings, and the contents. Q.S. At-Taubah (10): 122 is one of the Quranic materials taught to students of class X SMK (vocational school). Most of the 10th-grade students at SMKN (State Vocational high School) 2 Batu in learning Surah Al-Taubah are only limited to reading comprehension with lacking in understanding the meaning and content. This condition occurs due to the lack of teachers in implementing various learning models that are varied and innovative. This research is a type of Classroom Action Research (CAR) with the aim to improve students' ability to understand Quranic material in surah At Taubah. The procedure for carrying out this research consists of two cycles. Each cycle consists of four stages, namely planning, implementation, observation, and reflection. The results showed that by using the "Make A Match" model, student learning outcomes in the application of the law of reading nun/tanwin and mim sukun in reading the Qur'anic letters showed an increase. It is proven by the increase in the average results of daily tests and classical completeness values. The average value of the class increased from 66.8 to 76.5 in the first cycle and increased to 82 in the second cycle. The percentage of classical completeness before taking action by $54 \%$ increased to $75 \%$ in the first cycle and increased to $96 \%$ in the second cycle.
\end{abstract}

Keywords: Make a Match; Undertanding; Learning.

Abstrak. Pemahaman terhadap materi Al Qur'an pada siswa SMK meliputi pemahaman cara membaca, menjelaskan arti dan kandungannya. Q.S. At-Taubah (10): 122 merupakan salah satu materi Al Qur'an yang diajarkan pada siswa kelas X SMK. Sebagian besar siswa kelas X di SMKN 2 Batu dalam pembelajaran surat At Taubah hanya sebatas memahami bacaan saja dan kurang dalam memahami arti dan kandungannya. Hal ini terjadi diataranya karena kurangnya guru dalam menerapkan berbagai model pembelajaran yang variatif dan inovatif. Penelitian ini merupakan jenis Penelitian Tindakan Kelas (PTK) dengan tujuan untuk meningkatkan kemampuan siswa dalam memahami materi Q.S. At Taubah. Prosedur pelaksanaan Penelitian Tindakan Kelas ini terdiri dari dua siklus dan masing-masing siklus terdiri dari empat tahap, yaitu Perencanaan, Pelaksanaan, Observasi dan Refleksi. Hasil penelitian menunjukkan dengan penggunaan Make a Match, hasil belajar siswa dalam penerapan hukum bacaan nun mati/tanwin dan mim mati dalam bacaan surat-surat Al Qur'an menunjukkan peningkatan. Hal ini dibuktikan dengan adanya peningkatan rata-rata hasil ulangan harian dan nilai ketuntasan klasikal. Nilai rata-rata kelas meningkat dari sebelum dilakukan tindakan sebesar 66,8 menjadi 76.5 pada siklus I dan meningkat menjadi 82 pada siklus II. Persentase ketuntasan klasikal sebelum dilakukan tindakan sebesar 54\% meningkat menjadi 75\% pada siklus I dan meningkat menjadi $96 \%$ pada siklus II.

Kata Kunci: Make a Match; Pemahaman; Pembelajaran.

Copyright (C J-PAI: Jurnal Pendidikan Agama Islam. All Right Reserved.

This is an open-access article under the CC BY-SA license

(https://creativecommons.org/licenses/by-sa/4.0/).

Correspondence Address: jpai@uin-malang.ac.id 
Nur Azizah: Implementasi Pembelajaran Make A Match ...

\section{A. PENDAHULUAN}

Pendidikan Agama Islam merupakan mata pelajaran wajib dalam semua jenjang pendidikan, termasuk jenjang Pendidikan Sekolah Menengah Atas (SMK). Hal ini diatur dalam PP No. 19 Tahun 2005 tentang Standar Nasional Pendidikan yang memasukkan mata pelajaran agama dalam struktur kurikulum pendidikan nasional (Laoly, 2015). Salah satu materi Al Qur'an yang terdapat pada silabus mata pelajaran pendidikan Agama Islam adalah Q.S. At-taubah 122 yang diajarkan pada siswa kelas X SMK. Sebagian besar siswa kelas X AK di SMKN 2 Batu dalam pembelajaran surat At Taubah:122 hanya sebatas memahami bacaan saja dan kurang dalam memahami arti dan kandungannya. Hal ini ditunjukkan dari rendahnya nilai hasil belajar siswa, 7 dari 22 yang mampu dalam kompetensi menyebutkan arti dan menjelaskan makna Q.S. At Taubah 122 dan hadits terkait. Hal tersebut terjadi diataranya karena kurangnya guru dalam menerapkan berbagai model pembelajaran yang variatif dan inovatif. Guru masih menjadi sentral dalam pembelajaran, kurang mengoptimalkan aktivitas siswa, sehingga proses pembelajaran menjadi monoton dan kurang menarik. Untuk itu perlu dikembangkan model pembelajaran yang memungkinkan siswa dapat belajar secara aktif sehingga dapat memahami pelajaran secara cepat dan tertanam dalam memori siswa lebih lama (Fiteriani \& Arni, 2016; Mulyatiningsih, 2016).

Metode Make a Match merupakan salah satu model pembelataran yang aplikatif. Model pembelajan ini termasuk kedalam tipe pembelajaran kooperatif dengan pendekatan yang bersifat informatif sehingga dapat memungkinkan ketersediaan kondisi belajar yang aktif kepada para siswa. Dengan adanya unsur permainan, metode ini juga merupakan metode pembelajaran yang menyenangkan sehingga aktivitas belajar siswa baik secara kognitif maupun fisikdapat ditingkatkan. Dilain itu, penerapan metode ini dapat meningkatkan pemahaman siswa terhadap materi pelajaran dan memotivasi siswa untuk antusias dalam belajar. lebih dari itu, penggunaan metode pembelajaran Make a Match juga dapat melatih keberanian siswa untuk tampil presentasi dan disiplin menghargai waktu belajar" (Kusmanto, 2017; Miftahul Huda, 2014).

Aplikasi model pembelajaran dengan metode Make a Match dilakukan dengan melibatkan siswa secara komprehensif dalam kegiatan belajar mengajar. Pembelajaran materi dikemas dalam sebuah permainan mencari pasangan berdasarkan kartu soal dan jawaban. Sajian suasana belajar yang menyenangkan dalam bentuk game akan membuat para murid bersemangat dan tidak merasa bosan dengan proses pembelajaran. Dilain itu, mereka juga akan merasa termotivasi dalam permainan yang telah direncanakan oleh guru. Dengan adanya siswa yang lebih aktif, maka siswa akan lebih perhatian dengan materi yang disampaikan oleh guru dan tentu saja berakibat pada pemahaman materi pelajaran yang lebih optimal. Disamping meningkatkan keaktifan dalam belajar, metode pembelajaran Make a Match ini juga berimplikasi pada tingkat hasil belajar siswa yang lebih baik yang disebabkan oleh situasi belajar yang menyenangkan sehingga para murid secara otomatis terdorong untuk mempelajari materi pelajaran dengan baik (Marpaung, 2019; Tisha, 2017).

Model pembelajaran Make a Match merupakan model pembelajaran mencari pasangan. Setiap siswa mendapat sebuah kartu (bisa soal bisa jawaban), lalu secepatnya mencari pasangan yang sesuai dengan kartu yang ia pegang (Mardiyah, 2019; Trianto, 2011). Lebih lanjut sebagaimana dijelaskan oleh Supandi bahwa model pembelajaran Make a Match adalah suatu model pembelajaran dimana guru mempersiapkan kartu yang berisi persoalan permasalahan dan kartu yang berisi jawabannya. Setiap mendapatkan sebuah kartu soal dan berusaha menjawabnya, kemudian setiap siswa mencari kartu jawaban yang cocok dengan persoalannya. Dengan demikian secara garis besar siswa diklasifikasikan menjadi dua 
kelompok, yaitu kelompong yang membawa kartu soal dan kelompok yang membawa jawaban (Mardiyah, 2019; Yeti \& Mulya, 2018).

Tujuan penelitian tindakan kelas ini adalah mendiskripsikan pembelajaran Make a Match dapat meningkatkan kemampuan siswa dalam memahami materi Q.S. At Taubah 122. Prosedur pelaksanaan Penelitian Tindakan Kelas ini terdiri dari 2 siklus dengan masing-masing siklus yang terdiri dari empat tahapan, yaitu Perencanaan, Pelaksanaan, Observasi dan Refleksi.

Terdapat beberapa penelitian sebelumnya yang mengkaji tentang penerapan model pembelajaran Make a Match. Rahmawati, misalnya, dalam tulisannya menyebutkan bahwa berdasarkan hasil perhitungan uji hipotesis menggunakan program statistik SPSS 23 diperoleh nilai sig (2-tailed) $0,002,(0,002<0,05)$ sehingga $\mathrm{H}_{0}$ ditolak. Dari perhitungan tersebut dapat diperoleh bahwa model pembelajaran kooperatif tipe Make a Match efektif dalam pembelajaran IPS dan terdapat pengaruh dalam penggunaan model kooperatif tipe Make a Match di SD (Rahmawati, Darsono, \& Yulina, 2017).

Weny Glory Hidayati Halawa juga mengungkapkan dalam tulisannya bahwa model pembelajaran Make a Match ini juga berpengaruh positif dalam pembelajaran matematika tingkat SD utamanya dalam pembelajaran pecahan(Halawa, 2019). Selain itu, Dhestha Hazilla Aliputri menggunakan kartu bergambar dalam penelitiannya sebagai upaya penerapan model pembelajaran kooperatif dengan metode Make a Match untuk meningkatkan hasil belajar para siswa (Aliputri, 2018).

\section{B. METODE}

Penelitian ini menggunakan rancangan Penelitian Tindakan Kelas (PTK) model Kemmis dan McTaggart. Menurut Kemmis dan McTaggart, pelaksanaan tindakan dalam Penelitian Tindakan Kelas (PTK) meliputi empat alur (langkah), yaitu: (1) perencanaan tindakan (Plan); (2) pelaksanaan tindakan (act); (3) observasi (observe); dan (4) refleksi (reflect) (Ibrahim, 2019). Alur (langkah) pelaksanaan tindakan dimaksud dapat dilihat pada gambar berikut.

Gambar 1. Alur Pelaksanaan Tindakan dalam PTK (Rahmayanti \& Koeswanti, 2017)

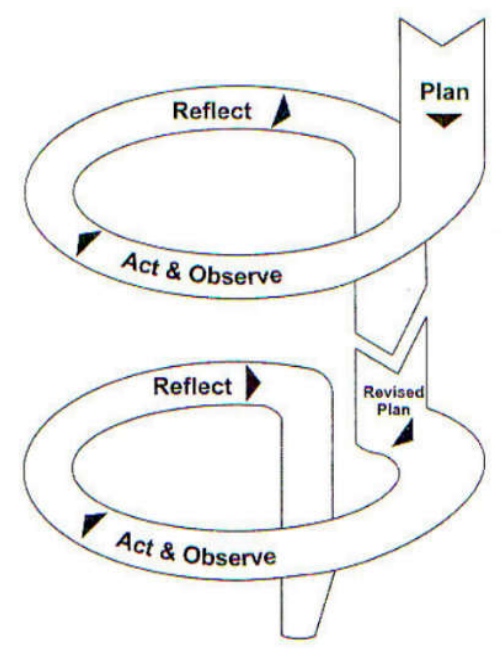

Subyek penelitian ini adalah siswa kelas X AK SMK Negeri 2 Batu yang berjumlah 22 siswa yang terdiri dari 19 siswa perempuan dan 3 siswa laki-laki. Pemilihan kelas X AK sebagai sebyek penelitian didasarkan pada pertimbangan masih rendahnya hasil belajar siswa yang ditunjukkan dari rendahnya nilai rata-rata kelas. Penelitian ini dilakukan dengan menggunakan metode penelitian tindakan kelas dan terdiri dari dua siklus. Langkah-langkah tiap siklus terdiri dari: perencanaan, pelaksanaan, tindakan, observasi dan refleksi. 
Nur Azizah: Implementasi Pembelajaran Make A Match ...

\section{HASIL DAN PEMBAHASAN}

Bagian ini memuat deskrisi pelaksanaan pembelajaran metode Make a Match pada materi membaca dan mengartikan Surat At-Taubah 122 dan hadist riwayat Buckhari Muslim tentang Menuntut Ilmu. Pelaksanaan pembelajaran terdiri dari dua siklus yang masing-masing siklus dilaksanakan dua kali pembelajaran. Siklus I dilaksanakan pada tanggal 19 Januari 2019 untuk pertemuan pertama dan 26 Januari untuk pertemuan kedua.

Pada pertemuan pertama, siswa yang hadir sebanyak 22 orang siswa, lengkap dan tidak ada yang absen. Pembelajaran diawali oleh guru dengan membuka salam, berdoa, dan guru memeriksa kehadiran siswa. Berikutnya guru membuka pelajaran dengan membaca al qur'an yang telah dipelajari di semester sebelumnya. Guru menyampaikan tema dan tujuan pembelajaran hari ini. Untuk mengetahui pemahaman siswa tentang materi menuntut ilmu dalam QS. At taubah122, guru melakukan dialog atau wawancara.

Berdasarkan dialog atau wawancara tersebut diketahui bahwa pemahaman siswa tentang belajar hanya untuk konteks formalitas saja. Padahal tujuan pembelajaran adalah siswa mampu melafalkan surat at Taubah 122 dan artinya sebagai dasar kewajiban untuk menuntut ilmu. Memasuki pembelajaran inti, guru mulai membagi siswa menjadi 4 kelompok secara acak. Setelah kelompok terbentuk, guru menjelaskan kegiatan yang akan dilakukan.

Setelah melakukan siklus pada tahap I, maka dilakukan sebuah tindakan reflektif. Hasil tersebut kemudian digunakan untuk perbaikan proses belajar mengajar pada siklus II. penjabaran hasil refleksi pada siklus I dapat diperhatikan pada tabel berikut:

Tabel 1. Hasil refleksi siklus I tentang pembelajaran surat Al-Taubah 122

\begin{tabular}{llll}
\hline \multicolumn{1}{c}{ Kekurangan } & \multicolumn{1}{c}{ Penyebab } & \multicolumn{2}{c}{ Alternatif Perbaikan } \\
\hline $\begin{array}{l}\text { Terdapat banyak siswa } \\
\text { yang kurang antusias }\end{array}$ & $\begin{array}{l}\text { Sejumlah siswa tidak } \\
\text { dalam membawa buku referensi }\end{array} \begin{array}{l}\text { Setiap siswa diharuskan } \\
\text { membawa buku referensi. }\end{array}$ \\
diskusi kelompok & $\begin{array}{l}\text { menakan } \\
\text { untuk dibaca (alqur'an) }\end{array}$ & \\
\hline $\begin{array}{l}\text { Terdapat anggota dalam } \\
\text { kelompok }\end{array}$ & $\begin{array}{l}\text { Anggota dalam kelompok } \\
\text { kurang/tidak aktif yang }\end{array}$ & $\begin{array}{l}\text { Setiap kelompok diberi } \\
\text { membuat kartu }\end{array}$ & $\begin{array}{l}\text { penjelasan untuk membuat } \\
\text { kartu yang dipasangkan } \\
\text { dengan kartu yang lain }\end{array}$ \\
\hline $\begin{array}{l}\text { Penyampaian } \\
\text { /presentasi hasil kurang } \\
\text { baik sehingga tidak dapat } \\
\text { memotivasi kelompok }\end{array}$ & Karena belum menguasai & $\begin{array}{l}\text { Dalam diskusi harus } \\
\text { memahami materi dulu }\end{array}$ \\
$\begin{array}{l}\text { lain untuk bertanya/ } \\
\text { menanggapi }\end{array}$ & & \\
\hline
\end{tabular}

Berdasarkan tabel di atas, hasil refleksi menunjukkan bahwa masih terdapat kekurangan yang tentunya harus dilakukan perbaikan dalam pelaksanaan pembelajaran lebih lanjut untuk peningkatan hasil belajar para siswa.

Oleh karena itu, diperlukan tindak lanjut sebagai perbaikan sebagaimana berikut:

\section{Perencanaan}

Pada tahap perencanaan ini, bebrapa persiapan untuk proses pembelajaran dilakukan yang antara lain meliputi; pengembangan RPP, pengembangan penggunaan media 
pembelajaran dengan power point, dan pengembangan Lembar Kegiatan Siswa (LKS). Pada tahap perbaikan RPP, pengembangan kompetensi dasar dilakukan dalam pemahaman surah at Taubah 122 dan hadits terkait. Dalam proses perbaikan RPP tersebut, peneliti melakukan analisa kedalaman materi pelajaran dengan alokasi waktu yang tersedia.

\section{Pelaksanaan}

Kegiatan pelaksanaan belajar mengajar dilakukan dalam durasi waktu 3 x 45 menit, yaitu jam pelajaran ke 1-3. Pada hari Jumat tanggal 2 Februari 2019. Dalam kegiatan pendahuluan guru melakukan aktivitas reflektif kepada siswa tentang materi yang dipelajari sebelumnya ( surat At Taubah 122). Kemudian, guru memberikan motivasi kepada siswa dengan cara mendengarkan bacaan surat at-Taubah 122 dan hadits terkait. Pada tahap pengelompokan, para siswa dilibatkan secara aktif dalam kegiatan kelompok. Para siswa diberikan lembar tugas untuk membantu siswa berperan aktif dalam bekerja menerapkan pembelajaran yang baru diterima. Beberapa kelompok termotivasi untuk menyelesaikan tugas yang diberikan. Antusias tersebut terjadi karena kelompok berkeinginan untuk menyelesaikan tugas lebih dahulu daripada kelompok yang lain. Guru melakukan pembagian siswa kedalam 4 kelompok dengan 5 siswa di setiap kelompok tersebut. Guru juga menyampaikan tujuan pembelajaran, yaitu siswa mampu melafalkan dan memahami kandungan surat at Taubah 122 dan hadits terkait tentang keutamaan ilmu.

Setelah memberikan pendahuluaan pembelajaran, guru menyajikan materi secara singkat tentang keutamaan ilmu berdasarkan surat at Taubah 122 dan hadits terkait. Para siswa, kemudian, diberi kesempatan membaca dan berusaha memahami masalah-masalah tersebut yang dilanjutkan dengan menjawab pertanyaan yang telah disediakan. Setelah itu, dilakukan diskusi kelompok atas permasalahan yang berhubungan dengan hadits terkait dengan keutamaan ilmu. Dalam diskusi, setiap kelompok mencocokkan kartu hasil diskusi dan dipresentasikan di depan kelas. Pada akhir kegiatan, dilakukan kegiatan refleksi atas hasil belajar dengan menggunakan lembar evaluasi yang telah disediakan.

\section{Observasi}

Catatan dan hasil pengamatan yang diperoleh dari proses belajar mengajar dianalisa dan enghasilkan data penelitian, yaitu: Berdasarkan data observasi atas proses belajar mengajar yang ada pada siklus II, diketahui bahwa penggunaan model pembelajaran Make a Match memberikan perkembangan dan kemajuan baik kepada para siswa dalam mengikuti proses kegiatan belajar mdngajar. Hal tersebut ditunjukkan dengan adanya kesiapan yang lebih baik daripada persiapan mereka di siklus I, utamanya dalam melakukan presentasi hasil. Lebih dari itu, model pembeljaran tersebut membuat proses berjalannya diskusi menjadi lebih aktif yang ditunjukan dengan munculnya berbagai pertanyaan atas materi pelajaran dan juga kemampuan siswa untuk menjawab pertanyaan-pertanyaan tersebut.

Model pembelajaran make a mach lebih diminatai oleh peserta didik berdasarkan penjelasan para siswa dari wawancara yang dilakukan. Para siswa tidak lagi canggung dan lebih berani dalam mengemukakan pendapat mereka terutama dalam mengusulkan kesimpulan hasil diskusi pada kelompok masing-masing. Penjabaran keunggulan siklus II dari siklus I dapat diuraikan sebagai beikut: Pertama, efisiensi penggunaan waktu pada siklus II lebih baik dari siklus I sehingga memungkinkan proses pembelajaran menjadi lebih efektif. Kedua, pada siklus II paa siswa mampu memahami substansi dan uraian permasalahan dengan cepatsebagai akibat dari adanya lembar kegiatan siswa (LKS) yangdi formulasi secara jelas. Lebih dari itu, pada fase 
Nur Azizah: Implementasi Pembelajaran Make A Match ...

tersebut siswa juga diberikan kesempatan untuk mempresentasikan secara lisan hasil diskusi setiap kelompok dengan maksut agar kelompok lain dapat memahami sekaligus memberikan catatan perbaikan atas hasil diskusi tersebut. Ketiga, klasifikasi kelompok telah mengetengahan keseimbangan anggota masing-masing kelompok berdasarkan siswa yang berkemampuan rendah dan yang berkemampuan tinggi. Keempat, tindakan lanjutan ini dianggap lebih baik dari sebelumnya didasarkan pada hasil pengamatan oleh dua orang observer atas kegiatan guru.

Selanjutnya Refleksi dilakukan kembali dengan mengasilkan data yang terangkum dalam tabel berikut:

Tabel 2. Data refleksi siklus II terkait proses pembelajaran keutamaan mencari ilmu berdasarkan QS. at Taubah(10): 122 dan hadits.

\begin{tabular}{llrl}
\hline \multicolumn{1}{c}{ Temuan } & \multicolumn{2}{c}{ Indikator } & \multicolumn{1}{c}{ Catatan } \\
\hline Keaktifan siswa dalam & Kemampuan siswa & dalam & Terdapat sebagaian \\
proses belajar mengajar & $\begin{array}{l}\text { mengkaji materi } \\
\text { mempresentasikan dan } \\
\text { kajian kepada } \\
\text { anggota kelompok }\end{array}$ & $\begin{array}{r}\text { hasil } \\
\text { sesama }\end{array}$ & \\
& kurang aktif & \\
\hline Pemaparan materi kajian & $\begin{array}{l}\text { Penjelasan terlalu melebar } \\
\text { diluar pokok bahasan }\end{array}$ & dari materi yang ditentukan & literature \\
\hline $\begin{array}{l}\text { Siswa termotivasi untuk } \\
\text { mlakukan penyampaian }\end{array}$ & $\begin{array}{l}\text { Siswa mampu memaparkan } \\
\text { kajian menggunakan media }\end{array}$ \\
hasil diskusi di depan & teknologi informasi. & \\
kelas yang berakibat & & & \\
terdorongnya siswa dari & & & \\
kelompok lain untuk & & & \\
melakukan hal yang sama & & & \\
\hline
\end{tabular}

Berdasarkan Tabel 2 diatas, hasil refleksi menunjukkan kemajuan dan perkembangan siswa dalam proses dan hasil pembelajaran dengan metode Make a Match. Dilain itu, para siswa terlihat lebih aktif dalam berinteraksi dalam kelompok.

Berdasarkan dari hasil evaluasi nilai yang didapat ada peningkatan hasil belajar tersebut dikarenakan adanya peningkatan pada aktivitas siswa dan guru dalam pembelajaran. Rata-rata aktivitas siswa mencapai $75 \%$ pada siklus I dan meningkat menjadi $81 \%$ pada siklus II. Sedangkan aktivitas guru dalam mengajar pada siklus I mencapai $73 \%$ pada siklus I meningkat menjadi 93\% pada siklus II.

\section{KESIMPULAN}

Kemampuan membaca dan menulis Al-Qur'an adalah merupakan hal yang sangat penting dalam proses pembelajaran setiap peserta didik yang harus menjadi perhatian guru PAI. Melalui penelitian tindakan kelas tentang penerapan model pembelajaran Make a Match untuk meningkatkan kemampuan siswa pada materi Q.S. At Taubah 122 di kelas X AK SMKN 2 Batu, dapat disimpulkan beberapa hal sebagai berikut:

1. Penerapan Make A Match dapat meningkatkan kemampuan siswa pada materi Q.S. At Taubah 122. Peningkatan kemampuan siswa dapat dilihat dari peningkatan hasil belajar siswa baik dalam nilai rata-rata kelas dan nilai ketuntasan klasikal. Nilai rata-rata kelas 
meningkat dari sebelum dilakukan tindakan sebesar 66.8 menjadi 76.5 pada siklus I dan meningkat menjadi 82 pada siklus II. Persentase ketuntasan klasikal sebelum dilakukan tindakan sebesar 54\% meningkat menjadi 75\% pada siklus II dan meningkat menjadi $96 \%$ pada siklus II. Pencapaian hasil belajar tersebut di atas telah melampaui indikator keberhasilan yang telah ditetapkan.

2. Peningkatan hasil belajar tersebut dikarenakan adanya peningkatan pada aktivitas siswa dan guru dalam pembelajaran. Rata-rata aktivitas siswa mencapai 75\% pada siklus I dan meningkat menjadi $81 \%$ pada siklus II. Sedangkan aktivitas guru dalam mengajar pada siklus I mencapai 73\% pada siklus I meningkat menjadi 93\% pada siklus II.

Berdasarkan hasil temuan baik secara teori maupun dilapangan yang diperoleh dari penelitian tindakan kelas, maka peneliti merasa perlu memberikan saran-saran, antara lain :

1. Bagi sekolah, hendaknya menjadi dorongan untuk dapat menciptakan kondisi yang memacu guru untuk dapat melaksanakan pembelajaran dengan menerapkan berbagai model pembelajaran yang sesuai. Termasuk memberikan fasilitas sarana dan prasarana yang dibutuhkan sesuai dengan kemampuan sekolah.

2. Bagi guru, diharapkan dapat lebih kreatif dan inovatif dalam pembelajaran, termasuk dalam pemilihan model pembelajaran yang dapat meningkatkan aktivitas siswa. Sehingga siswa tidak jenuh dan lebih aktif dalam pembelajaran dan pada akhirnya dapat meningkatkan kemampuan siswa.

\section{DAFTAR PUSTAKA}

Aliputri, D. H. (2018). Penerapan Model Pembelajaran Kooperatif Tipe Make A Match Berbantuan Kartu Bergambar Untuk Meningkatkan Hasil Belajar Siswa. Jurnal Bidang Pendidikan Dasar, 2(1A), 70-77. doi: 10.21067/jbpd.v2i1A.2351

Fiteriani, I., \& Arni, S. (2016). Model Pembelajaran Kooperatif Dan Implikasinya Pada Pemahaman Belajar Sains di SD/MI (Studi PTK di Kelas III MIN 3 WatesLiwa Lampung Barat). TERAMPIL: Jurnal Pendidikan Dan Pembelajaran Dasar, 3(2), 94-115. doi: 10.24042/terampil.v3i2.1191

Halawa, W. G. H. (2019). Pengaruh Model Pembelajaran Kooperatif Tipe Make A Match Terhadap Hasil Belajar Matematika Siswa Kelas V SD Negeri 060915 Jl Tb Simatupang Kecamatan Medan Sunggal Tahun Pembelajaran 2018/2019. Jurnal Ilmiah Aquinas, 2(2), 375-397. doi: 10.1234/jia.v2i2.558

Ibrahim, M. (2019). Peningkatan Kemampuan Bermain Peran Menggunakan Metode Demonstrasi Berbantuan Multimedia Film: Penelitian Tindakan Kelas terhadap Siswa Kelas XI MIPA 4 SMA Negeri 8 Kota Bandung Tahun Ajaran 2019/2020.

Kusmanto, H. (2017). Pengaruh Penerapan Model Pembelajaran Kooperatif Tipe Make A Match terhadap Kreativitas Siswa dalam Pembelajaran Matematika. Eduma: Mathematics Education Learning and Teaching, 6(1), 32-42.

Laoly, Y. H. Peraturan Pemerintah Republik Indonesia Nomor 13 Tahun 2015 tentang Perubahan Kedua Atas Peraturan Pemerintah Nomor 19 Tahun 2005 Tentang Standar Nasional Pendidikan. , $13 \S$ (2015). 
Nur Azizah: Implementasi Pembelajaran Make A Match ...

Mardiyah, H. (2019). Pengaruh Model Pembelajaran Make a Match (Mencari Pasangan)

Terhadap Hasil Belajar Siswa pada Mata Pelajaran Akidah Akhlak Di Kelas V MI al-Adli

Palembang. UIN Raden Fatah Palembang, Palembang.

Marpaung, T. (2019). Pelaksanaan Model Make a Match Dalam Meningkatkan Hasil Belajar. Jurnal Pena Edukasi, 5(4), 229-234.

Miftahul Huda. (2014). Cooperative Learning: Metode, Teknik, Struktur, dan Model Penerapan. Yogyakarta: Pustaka Pelajar.

Mulyatiningsih, E. (2016). Pengembangan Model Pembelajaran. Diakses Dari Http://Staff. Uny. Ac. Id/Sites/Default/Files/Pengabdian/Dra-Endang-MulyatiningsihMpd/7cpengembangan-Model-Pembelajaran. Pdf. Pada September.

Rahmawati, S. E., Darsono, D., \& Yulina, Y. (2017). Pengaruh Model Pembelajaran Kooperatif Tipe Make A Match Terhadap Hasil Belajar IPS. Jurnal Pedagogi, 6(1). Retrieved from http://jurnal.fkip.unila.ac.id/index.php/pgsd/article/view/13290

Rahmayanti, I. D. S., \& Koeswanti, H. D. (2017). Penerapan Model Make a Match Untuk Meningkatkan Hasil Belajar Matematika Materi Siswa Kelas IV SD Negeri Diwak. UNION: Jurnal Ilmiah Pendidikan Matematika, 5(3). doi: 10.30738/.v5i3.1060

Tisha, F. (2017). Penerapan Pembelajaran Kooperatif Tipe Make A Match Untuk Meningkatkan Keaktifan Dan Hasil Belajar Siswa Pada Mata Pelajaran Kompetensi Kejuruan Tkj Kelas X TKJ SMK Muhammadiyah 2 Yogyakarta (Skripsi, Fakultas Teknik). Fakultas Teknik. Retrieved from https://eprints.uny.ac.id/51011/

Trianto. (2011). Model-model Pembelajaran Inovatif Berorientasi Konstruktivistik: Konsep Landasan Teoritis - Praktis Dan Implementasinya (5th ed.). Jakarta: Prestasi Pustaka.

Yeti, H., \& Mulya, N. (2018). Penerapan Model Pembelajaran Kooperatif Tipe Make A Match Untuk Mengembangkan Motivasi Belajar. Al-Athfaal: Jurnal Ilmiah Pendidikan Anak Usia Dini, 1(2), 56-70. doi: 10.24042/ajipaud.v1i2.3906 